\title{
Decomposition rate, and carbon and nitrogen dynamics of Sphagnum litter: lessons from a peat bog
}

\author{
Evelin Ramóna PÉLI ${ }^{1 *}$, János NAGY ${ }^{2}$ and Dániel CSERHALMI ${ }^{3}$ \\ MTA-SZIE Plant Ecology Research Group, Szent István University, Institute of Botany and Ecophysiology, 2103 Gödöllö, \\ Páter K. 1. Hungary, ${ }^{*}$ e-mail: Peli.Evelin@mkk.szie.hu (corresponding author) \\ Szent István University, Institute of Botany and Ecophysiology, Faculty of Agricultural and Environmental Sciences, \\ 2103 Gödöllő, Páter K. 1. Hungary \\ Szent István University, Institute of Biology, Department of Botany, Faculty of Veterinarian Sciences, H-1078 Budapest, \\ Rottenbiller 50. Hungary
}

\begin{tabular}{|c|c|}
\hline ARTICLE INFO & ABSTRACT \\
\hline $\begin{array}{l}\text { RECEIVED AFTER REVISION } \\
\text { JANUARY } 2016 \\
\text { DOI } \\
\text { 10.3161/15052249PJE2016.64.2.007 } \\
\text { KEY wORDS } \\
\text { mass loss } \\
\text { C/N ratio } \\
\text { carbon and nitrogen release }\end{array}$ & $\begin{array}{l}\text { Decomposition rates and changes of carbon and nitrogen contents } \\
\text { of Sphagnum litter in mire vegetation can help to explore the eco- } \\
\text { logical effects of climate change and the role of environmental fac- } \\
\text { tors from a local to an ecosystem scale. The objective of the study } \\
\text { was to determine the relationship between mentioned parameters } \\
\text { in small and isolated Sphagnum dominated mires. Measurements } \\
\text { had been conducted throughout a year by placing litterbags filled } \\
\text { with Sphagnum biomass in three vegetation types (open peat bog, } \\
\text { poor fen, alder carr) of a mire ecosystem in Hungary. Peat decom- } \\
\text { position rates differed to a great extent; the slowest decomposi- } \\
\text { tion rate ( } 39.1 \pm 9.52 \%) \text { was in the alder carr, indicating that slower } \\
\text { decomposition could be characteristic for this kind of vegetation } \\
\text { type of mire. Between Sphagnum dominated microhabitats, open } \\
\text { peat bog showed medium }(65.57 \pm 4.05) \text { while poor fen the fastest } \\
\text { (68.61 } \pm 5.5) \text { rates in decomposition. The C/N ratio of the Sphag- } \\
\text { num litter showed significant decrease }(P<0.005) \text { in all studied } \\
\text { micro-environments. Slower N release was observed from litter of } \\
\text { Alnus dominated association ( } 31.3 \pm 6.9 \%) \text { compared to Sphagnum } \\
\text { dominated ones (56.5 } 5.3 \% \text { ). Our findings showed that the de- } \\
\text { composition rates were more dependent on vegetation type than } \\
\text { C/N ratio and this relationship was also revealed at a small spatial } \\
\text { scale. }\end{array}$ \\
\hline
\end{tabular}

\section{INTRODUCTION}

Decomposition is one of the most important processes in the biogeochemical cycling of ecosystems especially in the carbon cycle (Berg and McClaugherty 2008). The amount of available nutrients depends on the rate of decomposition and determines productivity, especially in mire ecosystems ( $\mathrm{Ha}$ raguchi et al. 2002). Decomposition rates are usually low in these ecosystems due to low temperature, water-logging, anoxic and acidic conditions and the low nutrient concentration of the litter (Aerts et al. 2006). These ecosystems can accumulate a large amount of organic matter, thus they are considered as the largest terrestrial carbon storage of the earth (Charman et al. 2013). As the main litter producers are Sphagnum mosses, the growth biomass accumulation and decomposition rates in these habitats mainly depend on local environmental conditions in them (i.e. in habitats), therefore understanding decomposition processes of this ecosystem can be an emphasized question of mire ecology. Decomposition rates mainly depend on the activity of microorganisms (Kulichevskaya et al. 2007) which are influenced to a great extent by specific substrates (Haragu chi et al. 2003) just as the amount of carbon available for dominant vegetation of a peatland (Limpens et al. 2008). Studies revealed that the nutrient conditions of the study site have stronger effect on the degree of decomposition rates than the quality of litter ( $\mathrm{Re} i$ jmánková and Houdková 2006). Changes 
of environmental factors also influence decomposition, thus raised nitrogen influx and temperature (Malmer and Wallén 1999) or fertilization (Bubier et al. 2007) would incu rease the rate of the decay processes.

Studies showed that different type of mires had significantly different decomposition rates which were higher in mineral poor fens than bogs (Moore et al. 2007). The rate of decomposition is strongly dependent on litter position within the peat profile, which decreased with depth (Moore et al. 2007). However, there were also differences between different types of fens as mineral-rich fens had higher decomposition rates than the basepoor fens (Verrhoeven and Toth 1995).

Some works reported a higher decomposition rate for Carex sp. litter than for peat mosses, which they attributed to the presence of sphagnols (phenolic compounds) in mosses (Verrhoeven and Toth 1995, Certini et al. 2014). Sphagnum species also showed interspecific differences in resistance to decomposition (Rochefort et al. 1990, Belyea 1996). Peat accumulation is higher in hummock formation than in hollow ones due to the lower decomposition rates, or to higher productivity, which means that the decay of hollow-species (like Sphagnum cuspidatum, Sphagnum fallax) is faster (Rochefort et al. 1990). Otherwise, plant associations dominated by different plant species reflect variable production rates (Péli et al. 2015) and, consequently, can influence the decomposition rates.

Changes in $\mathrm{C} / \mathrm{N}$ ratio of Sphagnum litter are also a good trait to indicate the environmental changes by controlling decay processes. Although the nitrogen content of peat mosses is low while it can be significant in case of bog's herbaceous plants (Aerts et al. 1999). The local microclimate (sunny and shady sites) basically determines the carbon cycle of the vegetation (Péli et al. 2015) which affects the $\mathrm{C} / \mathrm{N}$ ratio. A positive correlation showed between shady habitat and decreased $\mathrm{C} / \mathrm{N}$ ratio in case of hummock species, Sphagnum capillifolium (Manninen et al. 2011). Increased $\mathrm{C} / \mathrm{N}$ ratio was reported in hummock Sphagnum species responded to drought (Bu et al. 2013), as well.

In this study we report an in situ investigation of the relationship between decom- position rates and $\mathrm{C}, \mathrm{N}$ contents of Sphagnum litter in three plant associations of two Sphagnum dominated mires. This study was designed to compare decomposition rates and carbon, nitrogen contents estimated by Sphagnum litterbag incubation and investigate their relation to different habitats represented by different plant associations. The relative ecological importance of these variables at the local scale is essential for understanding responses of ecosystem processes to environmental changes. We hypothesised that the investigated parameters would correlate with different vegetation types and they can identify with characteristic features. Specifically, we assumed that (i) mass loss would be positively related to $\mathrm{C}, \mathrm{N}$ releases of litter bags; (ii) litter will decay a slower in Alnus carr than in Sphagnum dominated ones; (iii) carbon release would be significantly faster than nitrogen release; (iv) nutrient releases would differ between habitats, i.e. depend on plant association/composition.

\section{MATERIALS AND METHODS}

\section{Site description}

The vegetation at the study sites of Nyírestó and Báb-tava $\left(48^{\circ} 11^{\prime} 3^{\prime \prime} \mathrm{N}, 22^{\circ} 30^{\prime} 6^{\prime \prime} \mathrm{E}\right.$ and $\left.48^{\circ} 11^{\prime} 16^{\prime \prime} \mathrm{N}, 22^{\circ} 29^{\prime} 0^{\prime \prime} \mathrm{E}\right)$ is a mire ecosystem dominated by Sphagnum angustifolium and Sphagnum palustre, Eriophorum vaginatum, Eriophorum angustifolium, Juncus effusus, Carex lasiocarpa and Vaccinium oxycoccos (Szurdoki and Nagy 2002). Mires located in the Bereg Plain (NE Hungary), which are silted backwaters of Tisza River. The presence of raised bog associations on the Bereg-plain is southernmost occurrences in the plains of Europe. The mean annual precipitation is $630-660 \mathrm{~mm}$ and the mean annual temperature range is $9.4-9.5^{\circ} \mathrm{C}$ and the climate is moderately warm with cold winter. Average sizes of these ox-bows were less than 5 hectares. The study sites belong to Hortobágy National Park (Fig. 1.) and have been under protection for 60 years.

Investigations were carried out in three different associations of mires: open peat bog (Eriophoro vaginati-Sphagnetum), poor fen (Eriophoro angustifoliae-Sphagnetum) and al- 


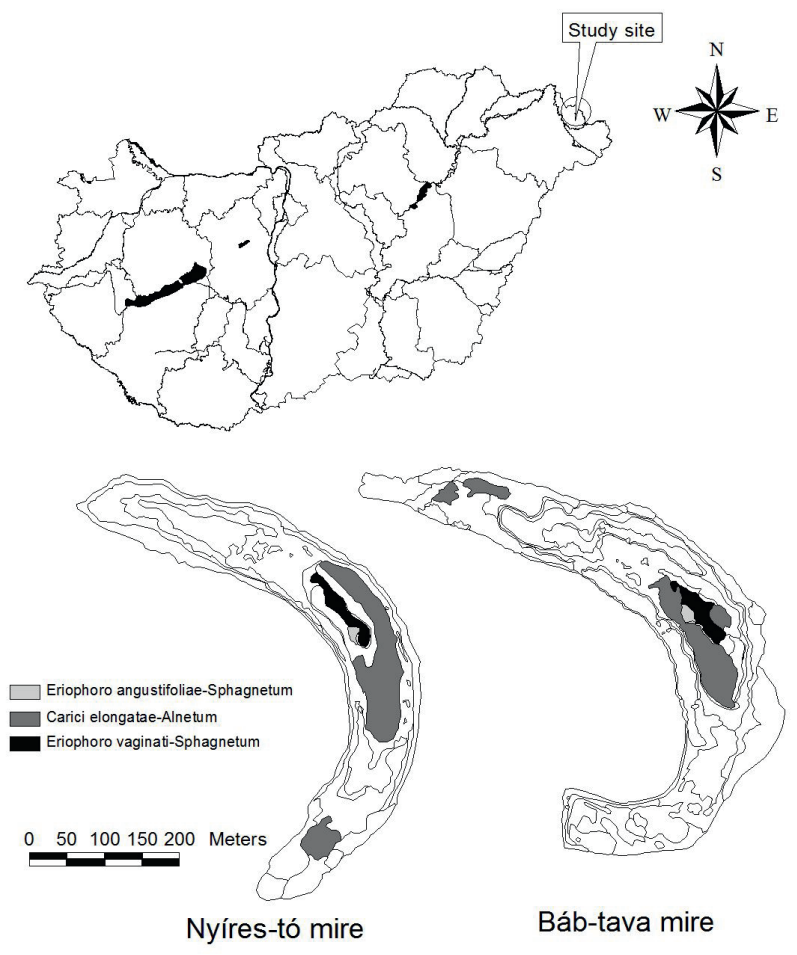

Fig. 1. Locations of the investigated mires in Hungary showing three different plant associations (Carici elongatae-Alnetum - alder carr, Eriophoro vaginati-Sphagnetum - open peat bog, Eriophoro angustifoliae-Sphagnetum - poor fen) in Nyíres-tó and Báb-tava mires, respectively.

der carr (Carici elongatae-Alnetum) (Fig. 1.). Open peat bog and alder carr were dominant in the middle of the bed. The dominant peat mosses were Sphagnum angustifolium and Sphagnum palustre. In the early 1960-ties, Báb-tava was burnt which caused the degradation of vegetation (Simon 1992). Due to arid years and human effects, the cover of tree-dominated associations increased and the habitats of protected rare species decreased. After the artificial flooding of the mires, degradation processes slowed down and quick regeneration started. The average $\mathrm{pH}$ value changed between 3.5 and 6.0. In the open peat bog and poor fen habitats, Sphagnum covered the entire surface besides vascular plants dominated by Eriophorum vaginatum, Eriophorum angustifolium, Juncus effusus, Carex lasiocarpa and Vaccinium oxycoccos. At the poor fen habitat the cover of Eriophorum angustifolium was higher while trees and shrubs were negligible. Alder carr dominated by mainly Alnus glutinosa mixing with Frangula alnus or Betula pubescens, Sphagnum coverage was low (Péli et al.
2015). Dominant herbs were Carex elongata, Lysimachia vulgaris and different mosses like Sphagnum angustifolium and Sphagnum fimbriatum were also present.

\section{Litter decomposition and carbon and nitrogen analysis}

Decomposition rates were determined in situ by litterbag technique in three associations of two peat bog areas. To eliminate the possible differences among the locations samples were collected from each association then mixed to get a well homogenous sample. At each location, Sphagnum angustifolium was used for decomposition samples as it was the most common and frequent peat moss in both investigated mires. Litterbags were used containing only one type of litter (Sphagnum angustifolium), based on the dominant and common peat moss in all experiment fields. On the other hand, the peat moss cover of the alder carr association was dominant while could not be found in large numbers. However, S. an- 
gustifolium was also used for the experiment in this habitat with the aim of comparing the rates of decomposition. Decomposition rates of alder trees (which were dominant in this association) are not relevant as they refer to other two sites and not during the one year of incubation. We sampled only capitula and the 10 upper centimetre parts (living biomass) of the mosses to make sure that these parts did not start to decay yet and all brownish parts were eliminated. The samples were collected at the end of the growing season in October. Materials were dried for 24 hours at $40^{\circ} \mathrm{C}$ and used for filling $10 \times 10 \mathrm{~cm}$ mosquito netting bags (mesh size $=0.3 \mathrm{~mm}$ in which water can flow through) with $1.0 \mathrm{~g}$ Sphagnum. Applied mesh size was provided for the natural decomposition processes allowing free movement of organic and inorganic matters in natural field condition. All bags were labelled with unique identification numbers and also their weight was measured. Samples were placed horizontally and buried at approximately $15 \mathrm{~cm}$ from the surface, at a distance of 1-2 meters from each other in all three associations in October. Six litterbags were sampled from each site after 12 months of decomposition. After one year of incubation, the litterbags were removed and cleaned of extraneous litters, soil particles, foreign materials and roots, then the contents were dried for 24 hours at $40^{\circ} \mathrm{C}$ and weighed. The relative mass loss was calculated from the initial mass and the mass after removal from the field. Removed Sphagnum litter was also analysed for carbon and nitrogen content as described below.

Decomposition rates were expressed as percentage of mass loss after 12 month of field burial as follows:

$$
\begin{array}{r}
\text { Decomposition rates }(\%)=\left(\left(w_{0}-w_{1}\right) / w_{0}\right) \\
\times 100
\end{array}
$$

where $w_{0}$ is the weight of sample in the bag before burial and $w_{1}$ is the weight of the same content after 12 months.

Constant decomposition ( $\mathrm{k}$-values) was calculated by Ols on's (1963) model:

$$
X t=X 0 e^{-k t}
$$

where $\mathrm{X} 0$ and $\mathrm{X} t$ are litter dry weight at the beginning of incubation and at time re- spectively, $t$ is time in days (365), and $k$ is the constant of decomposition. We performed the calculation of $k$ linear regressions of $\ln$ $(\mathrm{X} 0 / \mathrm{X} t) v s$ time. The $k$ constant was calculated for the complete incubation (365 days) in the field.

Sphagnum decomposed samples were oven-dried $\left(40^{\circ} \mathrm{C}\right)$ to constant weight and finely ground to be analysed for $\mathrm{C}$ and $\mathrm{N}$ by flash combustion method using a Carlo-Erba (Fisons) NA 1500 elemental analyser. Pure data of carbon and nitrogen content refer to $\mathrm{mg}$ $\mathrm{kg}^{-1}$ from which C:N ratio of Sphagnum litter was calculated. Control samples, which were used to estimate the initial $\mathrm{C}$ and $\mathrm{N}$ contents of the litter, were analysed after autumn collection prior to putting samples to litter bags and placing them for one year in all the three habitats of peat bogs.

For each litter bag the release of $\mathrm{C}, \mathrm{N}$ was calculated as percentage (\%) of initial total content:

Carbon, nitrogen release $(\%)=\left(\left(x_{0} w_{0}-\right.\right.$ $\left.\left.x_{1} w_{1}\right) /\left(w_{0} w_{0}\right)\right) \times 100$

where $x_{0}$ is the mean nutrient concentration of plant litter before burial and $x_{1}$ is the nutrient concentration in the litter bag after one year of burial.

\section{Statistical analyses}

Differences among mass loss, $\mathrm{C} / \mathrm{N}$ ratio, $\mathrm{C}$ and $\mathrm{N}$ release of Sphagnum litters at different plant associations were analysed by the Student's $t$-test and analyses of variance (ANOVA) using Statistica 5.1 software. One- and two-way ANOVA was applied to examine significant differences between decomposition rates, and $\mathrm{C}$ and $\mathrm{N}$ releases; Tukey's HSD test was used to test for significant differences in variability among plant associations and between habitats.

\section{RESULTS}

Analysis of the litterbag samples revealed differences in decomposition rates between association types (Table 1) as well as between mires. The decomposition rates of biomass 
Table 1. Sphagnum litter decomposition in three plant: mass loss, the constant of decomposition rates (k-values). Different letters indicate statistically significant differences of the same association between different habitats $(P<0.005)$. Statistically significant differences $(P<0.01)$ between different associations in the same habitat are indicated by an asterisk. Differences were compared using Student's $t$-test. Control samples were analyzed in autumn before the litter bag experiment was started. Results are shown as \pm SE of mean $(n=6)$.

\begin{tabular}{|c|c|c|c|c|}
\hline \multirow{2}{*}{ Site } & \multirow{2}{*}{ Plant association } & \multicolumn{3}{|c|}{ Field incubation } \\
\hline & & $\begin{array}{c}\text { Mean mass } \\
\text { loss }(\%)\end{array}$ & $\begin{array}{c}k \text {-values } \\
\left(\text { year }^{-1}\right)\end{array}$ & $\mathrm{C}: \mathrm{N}$ ratio \\
\hline Nyíres-tó & Carici elongatae-Alnetum & $39.10 \pm 9.52 \mathrm{a}^{*}$ & $0.0014 \pm 0.0004 \mathrm{a}^{*}$ & $26.38 \pm 1.57$ \\
\hline \multirow[t]{2}{*}{ Mire } & Eriophoro vaginati-Sphagnetum & $65.57 \pm 4.05$ & $0.0029 \pm 0.0003$ & $27.80 \pm 1.47$ \\
\hline & Eriophoro angustifoliae-Sphagnetum & $65.93 \pm 9.34$ & $0.003 \pm 0.0008$ & $29.86 \pm 4.63$ \\
\hline Báb-tava & Carici elongatae-Alnetum & $62.78 \pm 5.64 b$ & $0.0027 \pm 0.00004 b$ & $30.18 \pm 3.41$ \\
\hline \multirow[t]{3}{*}{ Mire } & Eriophoro vaginati-Sphagnetum & $64.26 \pm 8.57$ & $0.0029 \pm 0.00006$ & $29.48 \pm 3.60$ \\
\hline & Eriophoro angustifoliae-Sphagnetum & $68.61 \pm 5.50$ & $0.003 \pm 0.0005$ & $25.07 \pm 2.65$ \\
\hline & Control & $37.04 \pm 2.44$ & & \\
\hline
\end{tabular}

increased in the order alder carr $<$ open peat bog $<$ poor fen (Table 1) (significant differences by Tukey's test between alder carr and Sphagnum dominated ones) similarly as $\mathrm{C} / \mathrm{N}$ ratio in case of Nyíres-tó mire (Fig. 2a). The largest mass loss was detected in case of poor fen which reflects increased decomposition in both mires. To examine the variance of Nyíres-tó mire results showed significant differences between two Sphagnum dominated associations and alder carr $(P<0.01)$ considering decomposition rates (Table 1). Comparing two habitats (Nyíres-tó and Báb-tava mires) significant differences in decomposition rates were observed only at alder carr site $(P<0.005)$. In situ decomposition litterbags study showed that the litter mass loss after one year of decomposition varied between $63 \%$ and $69 \%$ in the case of Báb-tava mire and $39 \%$ and $66 \%$ for Nyíres-tó mire, respectively. Poor fen showed the largest mass loss (69\%) due to increased decomposition processes (Table 1).

Measured nitrogen content of litters varied more than the carbon ones which implied a progressive decrease in $\mathrm{C} / \mathrm{N}$ ratio compared to control (Fig. 2a). Carbon/Nitrogen con- tents showed significant decrease $(P<0.005)$ in all investigated associations compared to control (Fig. 2a). Otherwise, there was a small variability in $\mathrm{C} / \mathrm{N}$ ratios after one year of decomposition between associations, which did not show significant differences. The most significant effects in terms of $\mathrm{C} / \mathrm{N}$ ratio were observed in the poor fen site, with the smallest value (68\%) (Fig. 2a). However, there were no significant differences between the habitats or the associations. Following one year incubation, the highest value $(30.18 \pm 3.4)$ in $\mathrm{C} / \mathrm{N}$ ratio was observed at the alder carr habitat of Báb-tava which was less with about $20 \%$ than control $(37.04 \pm 2.44)$ (Table 1$)$.

The release of $\mathrm{C}$ was significantly $(P<0.005)$ different by Tukey's test between plant associations as well as between of habitats (Nyíres-tó and Báb tava) (Fig. 2b, Table 2). Particularly lower $\mathrm{C}$ release was found in alder carr association than in Nyíres-tó mire. $\mathrm{N}$ release in alder carr site was slower than Sphagnum dominated associations (Fig. 2c). Nitrogen release differed between habitats and plant associations (Table 2). The release of both nutrients significantly differed between plant associations with interaction be- 

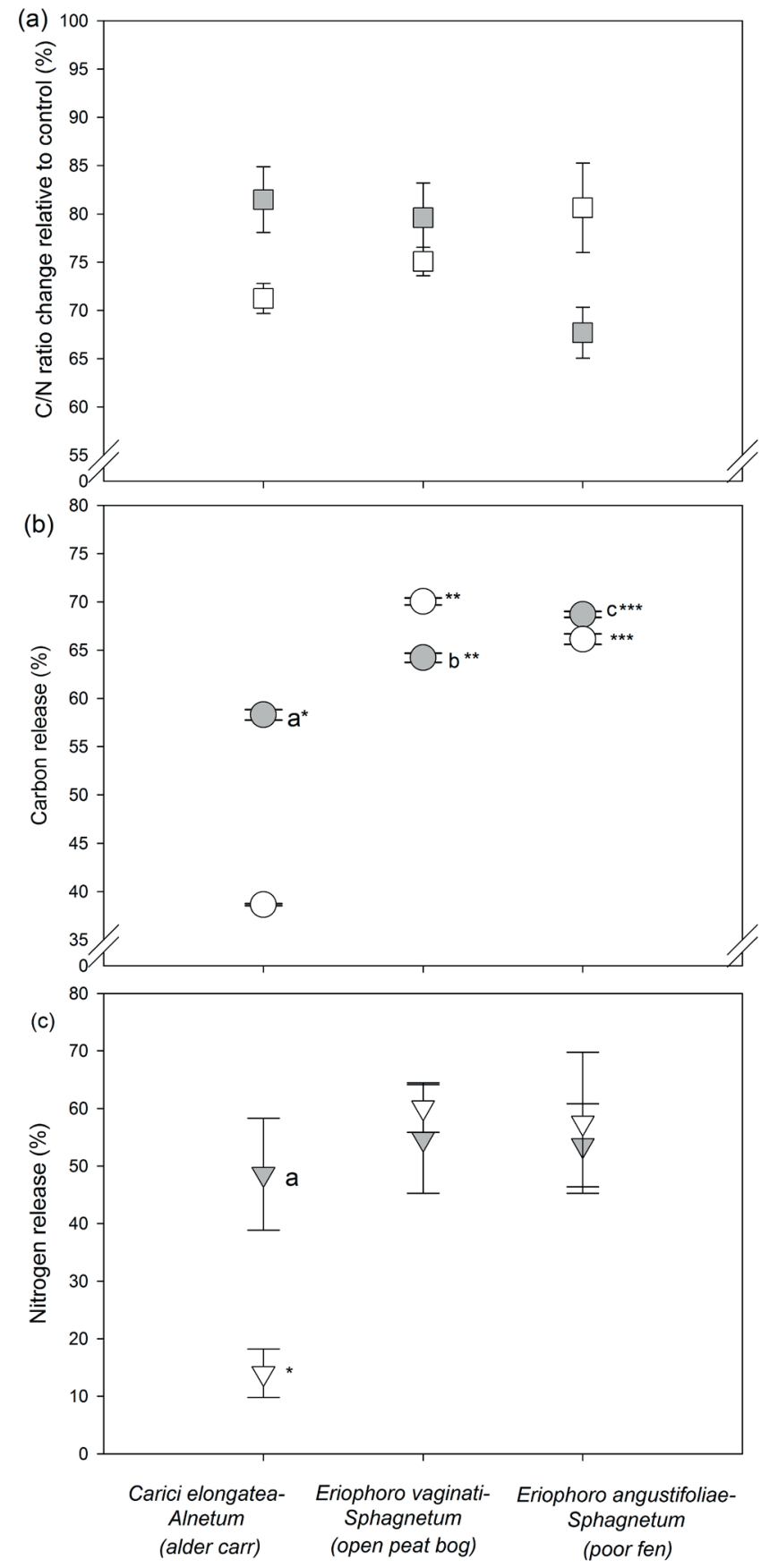

Fig. 2. C/N ratio of Sphagnum litter in control \% (a) and mean percentage release of carbon (b), nitrogen (c) from the Sphagnum litter of three different associations studied of Nyíres-tó ( $\mathrm{C} / \mathrm{N}$ ratio $-\square$; $\mathrm{C}$ release $-\mathrm{O} ; \mathrm{N}$ release $-\nabla)$ and Báb-tava $(\mathrm{C} / \mathrm{N}$ ratio $-\mathbf{\square} ; \mathrm{C}$ release $-\bullet ; \mathrm{N}$ release $-\boldsymbol{\nabla})$ mires after one year of burial. In Fig. (a) all data are significantly different from control values $(P<0.0001)$. In Figs (b) and (c) different letters indicate statistically significant differences of the same association between different habitats $(P<0.005)$. Statistically significant differences $(P<0.01)$ between different associations in the same habitat are indicated by an asterisk. Control samples were analyzed after autumn collection before the experiment. Error bars presented standard deviation $(n=6)$. 
Table 2. Two-way ANOVA results for $\mathrm{N}$ and $\mathrm{C}$ release from Sphagnum litter after one year of burial. The two independent variables are habitat (Nyíres-tó and Báb-tava mires) and plant association types (Eriophoro vaginati-Sphagnetum - open peat bog, Eriophoro angustifoliae-Sphagnetum - poor fen, Carici elongatae-Alnetum - alder carr). F - value of ANOVA; df - degree of freedom; $P$ value - probability value of significance

\begin{tabular}{llccc}
\hline Nutrient & \multicolumn{1}{c}{ Source } & $\mathrm{F}$ & $\mathrm{df}$ & $P$ value \\
\hline $\mathrm{N}$ & Habitat & 2.27 & 1 & 0.157 \\
& Plant association & 9.62 & 2 & $<0.005$ \\
& Habitat x plant association & 9.95 & 2 & $<0.005$ \\
& & & \\
$\mathrm{C}$ & Habitat & 735.2 & 1 & $<0.005$ \\
& Plant association & 4113.7 & 2 & $<0.005$ \\
& Habitat x plant association & 1644.6 & 2 & $<0.005$ \\
\hline
\end{tabular}

tween investigated variables. There was significant differences only in $\mathrm{N}$ release of alder carr habitats (Fig. 2c).

Significant positive correlation $(P<0.0001)$ was found between in decomposition rates, carbon and nitrogen release respectively, all indicating a net loss of nutrients (Fig. 3). The mean annual release of $C(61 \pm 11 \%)$ was significantly higher $(P<0.0001)$ than $\mathrm{N}(37 \pm 15 \%)$ nutrient loss.

\section{DISCUSSION}

Our data, sampled at three plant associations of two mires indicate significant differences in Sphagnum litter decomposition associated with dynamics of C, N content of Sphagnum litters in a relatively small separated area. A tight correlation between decomposition and nutrient release was revealed even in the case of different plant associations.

The difference between decomposition rates was mostly determined by the quality of leaf-litter inside each ecosystem (Aerts 1997) which changed with spatial and temporal diversity of environmental factors (Braga zza et al. 2008). The smallest mass loss was detected in Carici elongatae-Alnetum association (alder carr) $(39.1 \pm 9.5 \%)$ which is more than double of that reported in Dutch peatlands (Hoorens et al. 2003). Sphagnum dominated associations showed higher decomposition rates than alder carr. Similarly, $\mathrm{CO}_{2}$ flux measurements of the open peat bog habitat of Nyíres-tó mire (Péli et al. 2015) showed also higher $\mathrm{CO}_{2}$ uptake (increased activity) in any season than alder carr ones. Results can suggest that the decreased nitrogen availability limited the activity of microbial communities

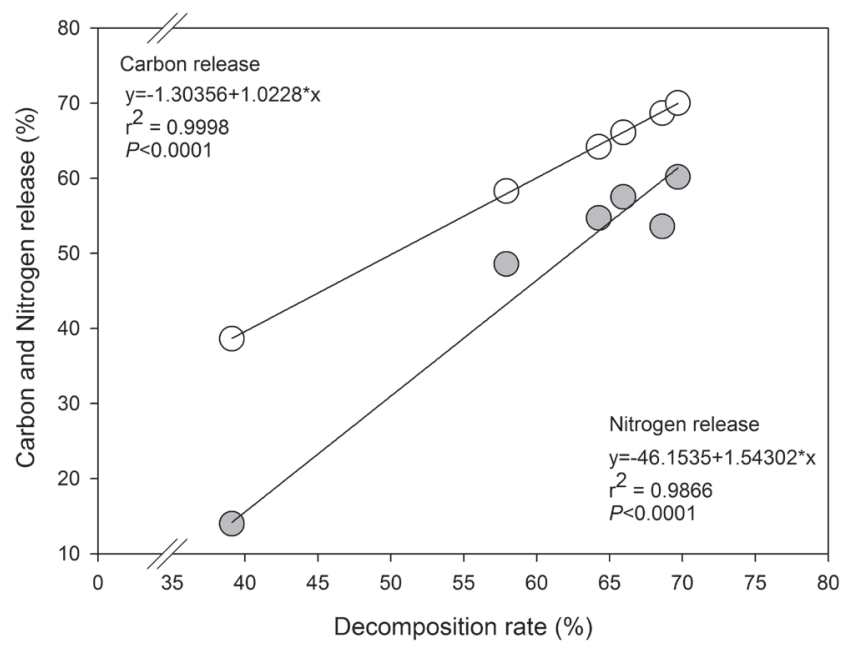

Fig. 3. Relationship between decomposition rates and the carbon, nitrogen release, respectively ( $\mathrm{O}$ indicated the carbon and $\bullet$ nitrogen release). Data represent three different associations of Nyíres-tó and Báb-tava mires; mean values were calculated based on six litter bags retrieved after 1 year of incubation. 
in Sphagnum dominated associations (poor fen and open peat bog) in contrast with carbon, which is easily accessible (Bragazza et al. 2007). The investigated Hungarian sites showed significantly higher decomposition than the northern peat bogs, e.g. mass loss of Canadian peat bogs were $13-17 \%$ (Waddingto et al. 2003). It is not only due to the different climatic zones since decomposition rates showed differences in certain Sphagnum species (Johnson and Damman 1991): hollow former species (e.g. Sphagnum cuspidatum) showed half as high decomposition rates than hummock former Sphagnum fuscum. Namely, based on the microtopography of mires, differences were found in decomposition rates between hummock and hollow formations (Nungesser 2003, Wu et al. 2011). The decay rate of hummock forming Sphagnum species is smaller than that of hollow species as they retain their physiological structures for a longer time under peat layer (Rochefort et al. 1990, Johnson et al. 1990, Johnson and Damman, 1991). Therefore, peat accumulation is faster in the case of hummock than hollow (Ohloson and Dahlberg 1991), the latter's decomposition rates are higher than ridge (Johnson and Damman 1993, Limpens and Berendse 2003). In our investigated mires, the dominant hollow former peat moss Sphagnum angustifolium showed faster decomposition rates than both of hummocks' and hollow former peat mosses' which were reported from northern areas (Waddington et al. 2003, Moore et al. 2007). Results also showed differences in decomposition rates inside a relatively small association due to presumably litter quality, different bacterial composition and anaerobic properties. It should be noted that the Canadian peat mosses are typically raised bog species which are not found on the present area of Hungary.

Consequently, decomposition (also mineral and carbon cycles) is considerably determined by characteristic features and compositions of litter from dominant plant species of a certain ecosystem. Otherwise, Actinomyces species which live on the roots of Alnus glutinosa insure continuous high nitrogen supply of alder trees contribute to delaying decomposition of dead plant material. It can partly explain the smallest mass loss in alder carr habitat.
Increased decomposition of Eriophoro angustifoliae-Sphagnetum association (poor fen) in the case of Báb-tava could be attributed to substantial disturbance of the area, as the mire was highly damaged in the 1960's (Simon 1992), while the nutrient content should have increased. The reason is that considerable part of the mire was burnt in the early 1960-ties on the other hand Báb-tava is surrounded by maize fields which caused pollution by fertilizers.

Sphagnum dominated associations were characterised by a higher $\mathrm{N}$ mineralisation compared to alder carr, which resulted faster litter decomposition. Carbon release was more significantly correlated with decomposition (mass loss) than the release of nitrogen related to litter quality.

Nitrogen immobilization depending on the plant association type could also show differences between Sphagnum dominated vegetation (Bragazza et al. 2008). Otherwise the ratio of element contents and losses is significantly higher in the case of our mires following one year decomposition compared to northern boreal bogs (Thormann et al. 1999, Certini et al. 2014). Lower N content and higher $\mathrm{C} / \mathrm{N}$ ratio can be observed in Sphagnum dominated associations than in Alnus ones of Nyíres-tó similarly to Glenn's with co-authors (Glenn et al. 2006) comparable study. In this study, at the poor fen site they measured less than half of total $\mathrm{N}$ content and two times greater $\mathrm{C} / \mathrm{N}$ ratio of Sphagnum spp. than that of Carex species. On the other hand, Sphagnum did not show great differences in carbon, nitrogen contents for a lack of senescence and the seasonal variations hardly appeared in $\mathrm{C} / \mathrm{N}$ ratios (C ertini et al. 2014). Some works reported a negative correlation between decomposition rates and $\mathrm{C} / \mathrm{N}$ ratios and a positive correlation between the former and total $\mathrm{N}$ content (Updegraff et al. 1995, Szu migalski and Bayley 1996).

\section{CONCLUSIONS}

Significant differences in terms of litter decomposition rates between the Sphagnum dominated areas and Alnus-covered (alder carr) area were found in the mires of Bereg plain. A higher mass loss was associated with 
Sphagnum dominated areas and lower decomposition rates with Alnus dominated association. Differences in $\mathrm{C} / \mathrm{N}$ ratio might be linked to the characteristic features of habitat vegetation. Different plant functional types living under different physical and biotic conditions were expressed in the litter quantity and quality of certain microhabitats. Decomposition rates were highly variable among plant associations. The rate of nutrient release and that of decomposition were significantly correlated. These results help to reveal the role of certain plant associations of mire ecosystem in the carbon cycle since they have basic role in controlling the carbon balance. Based on decomposition and the carbon and nitrogen content of the investigated type of ecosystem acts consequently as $\mathrm{C}$ sinks. The climatic effects on peatland vegetation basically influence their plant composition and their metabolisms which reflected a shift in decomposition and nutrient contents.

ACKNOWLEDGMENTS: The authors acknowledge the financial support of the projects OTKA-PD 109445 and the János Bolyai Research Scholarship of the Hungarian Academy of Sciences. This work was also supported by the Szent Istvan University, Research Centre for Excellence - 9878-3/2015/ FEKUT. We thank the Management of Hortobágy National Park (Debrecen) for the permission to conduct the studies in the territory of the national park.

\section{REFERENCES}

Aerts R. 1997 - Climate, leaf litter chemistry and leaf litter decomposition in terrestrial ecosystems: a triangular relationship - Oikos, 79: 439-449.

Aerts R., van Logtestijn C.R.S.P., Karlsson C.P.S. 2006 - Nitrogen supply differentially affects litter decomposition rates and nitrogen dynamics of sub-arctic bog species - Oecologia, 146: 652-658.

Aerts R., Verhoeven J.T.A., Whigham D.F. 1999 Plant-mediated controls on nutrient cycling in temperate fens and bogs - Ecology, 80: 2170-2181.

Belyea L.R. 1996 - Separating the effects of litter quality and microenvironment on decomposition rates in a patterned peatland - Oikos, 66: 269-278.
Berg B., McClaugherty C. 2008 - Plant Litter: Decomposition, Humus Formation, Carbon Sequestration - Springer Verlag, Berlin, 340 pp.

Bragazza L., Buttler A., Siegenthaler A., Mitchell E.A.D. 2008 - Plant Litter Decomposition and Nutrient Release in Peatlands Carbon Cycling in Northern Peatlands (Geophysical Monograph Series) - 184: 99-110.

Bragazza L., Siffi C., Iacumin P., Gerdol R. 2007 Mass loss and nutrient release during litter decay in peatland: The role of microbial adaptability to litter chemistry - Soil Biol. Biochem. 39: 257-267.

Bu Z-J., Zheng X-X., Rydin H., Moore T., Ma J. 2013 - Facilitation vs. competition: Does interspecific interaction affect drought responses in Sphagnum? - Basic Appl. Ecol. 14: 574-584.

Bubier J.L., Moore T.R., Bledzki L.A. 2007 - Effects of nutrient addition on vegetation and carbon cycling in an ombrotrophic bog Global Change Biol. 13: 1168-1186.

Certini G., Vestgarden L.S., Forte C., Tau Strand L. 2014 - Litter decomposition rate and soil organic matter quality in a patchwork heathland of Southern Norway - Soil Disc. 1: 267-294.

Charman D.J., Hohl V., Beilman D.W., Blaauw M., Booth R.K.,. Yu Z.C., Zhao Y. 2013 - Climaterelated changes in peatland carbon accumulation during the last millennium - Biogeosciences, 10: 929-944.

Glenn A.J., Flanagan L.B., Syed K.H., Carlson P.J. 2006 - Comparison of net ecosystem $\mathrm{CO}_{2}$ exchange in two peatlands in western Canada with contrasting dominant vegetation, Sphagnum and Carex - Agricult. Forest Meterol. 140: 115-135.

Haraguchi A., Hasegawa C., Hirayama A., Kojima H. 2003 - Decomposition activity of peat soils in geogenous mires in Sasakami, central Japan - Eur. J. Soil Biol. 39: 191-196.

Haraguchi A., Kojima H., Hasegawa C., Takahashi Y., Iyobe T. 2002 - Decomposition of organic matter in peat soil in a minerotrophic mire Eur. J. Soil Biol. 38: 89-95.

Hoorens B., Aerts R., Stroetenga M. 2003 - Does initial litter chemistry explain litter mixture effects on decomposition? - Oecologia, 137: 578-586.

Johnson L.C., Damman A.W.H. 1991 - Speciescontrolled Sphagnum decay on a South Swedish raised bog - Oikos, 61: 234-242. 
Johnson L.C., Damman A.W.H. 1993 - Decay and its regulation in Sphagnum peatlands - Adv. Bryol. 5: 249-296.

Johnson L.C., Damman A.W.H., Malmer N. 1990 - Sphagnum macrostructure as an indicator of decay and compaction in peat cores from an ombrotrophic south Swedish peat bog - J. Ecol. 78: 633-647.

Kulichevskaya I.S., Belova S.E., Kevbrin V.V., Dedysh S.N., Zavarzin G.A. 2007 - Analysis of the Bacterial Community Developing in the Course of Sphagnum Moss Decomposition Microbiology, 76: 621-629.

Limpens J., Berendse F. 2003 - How litter quality affects mass loss and $\mathrm{N}$ loss from decomposing Sphagnum - Oikos, 103: 537-547.

Limpens J., Berendse F., Blodau C., Canadell J.G., Freeman C., Holden J., Roulet N., Rydin H., Schaepman-Strub G. 2008 - Peatlands and the carbon cycle: from local processes to global implications - a synthesis - Biogeosci. Disc. 5: 1379-1419.

Malmer N., Wallén B. 1999 - The dynamics of peat accumulation on bogs: mass balance of hummocks and hollows and its variation throughout a millennium - Ecography, 22: 736-750.

Manninen S., Woods C., Leith I.D., Sheppard L.J. 2011 - Physiological and morphological effects of long-term ammonium or nitrate deposition on the green and red (shade and open grown) Sphagnum capillifolium - Environ. Experiment. Bot. 72: 140-148.

Moore T.R., Bubier J.L., Bledzki L. 2007 - Litter Decomposition in Temperate Peatland Ecosystems: The Effect of Substrate and Site Ecosystems, 10: 949-963.

Nungesser M.K. 2003 - Modelling microtopography in boreal peatlands: hummocks and hollows - Ecol. Model. 165: 175-207.

Ohlson M., Dahlberg B. 1991 - Rate of peat increment in hummock and lawn communities on Swedish mires during the last 150 years Oikos, 61: 369-378.

Olson J.S. 1963 - Energy storage and the balance of producers and decomposers in ecological systems - Ecology, 44: 322-331.
Péli E.R., Nagy J., Cserhalmi D. 2015 - In situ measurements of seasonal productivity dynamics in two Sphagnum dominated mires in Hungary - Carpath. J. Earth Env. 10: 231-240.

Rejmánková E., Houdková K. 2006 - Wetland plant decomposition under different nutrient conditions: what is more important, litter quality or site quality? - Biogeochemistry, 80: 245-262.

Rochefort L., Vitt D.H., Bayley S.E. 1990 - Growth, production, and decomposition dynamics of Sphagnum under natural and experimentally acidified conditions - Ecology, 71: 1986-2000.

Simon T. 1992 - Vegetation change and the protection of the Csaroda relic mires, Hungary Acta Soci. Botanic. Polon. 61: 63-74.

Szumigalski A.R., Bayley S.E. 1996 - Decomposition along a bog to rich fen gradient in central Alberta, Canada - Can. J. Bot. 74: 573-81.

Szurdoki E., Nagy J. 2002 - Sphagnum dominated mires and Sphagnum occurrences of NorthHungary - Folia historico-naturalia musei Matraensis, 26: 67-84.

Thormann M.N., Szumigalski A.R., Bayley S.E. 1999 - Aboveground peat and carbon accumulation potentials along a bog-fen-marsh wetland gradient in southern boreal Alberta, Canada - Wetlands, 19: 305-317.

Updegraff K., Pastor J., Bridgham S.D., Johnston C.A. 1995 - Environmental and substrate controls over carbon and nitrogen mineralization in northern wetlands - J. Appl. Ecol. 5: 151-163.

Verrhoeven J.T.A., Toth E. 1995 - Decomposition of Carex and Sphagnum litter in fens: effect of litter quality and inhibition by living tissue homogenates - Soil Biol. Biochem. 27: 271-275.

Waddington J.M., Rochefort L., Campeau S. 2003 - Sphagnum production and decomposition in a restored cutover peatland - Wetl. Ecol. Manag. 11: 85-95.

Wu J.N.T., Roulet T.R., Moore Lafleur P., Humphreys E. 2011 - Dealing with microtopography of an ombrotrophic bog for simulating ecosystem-level $\mathrm{CO}_{2}$ exchanges - Ecol. Model. 222: 1038-1047. 